\title{
PRELIMINARY MYCOCHEMICAL, GAS CHROMATOGRAPHY-MASS SPECTROSCOPY ANALYSIS, AND ANTIMICROBIAL PROPERTIES OF CALOCERA VISCOSA (PERS.) FR.
}

\author{
NAVEEN KUMAR NAIK S, ASHWATHANARAYANA R, RAJA NAIKA
}

Department of P.G Studies and Research in Applied Botany, Jnana Sahyadri, Kuvempu University, Shankaraghatta, Shimoga, Karnataka - 577451, India. Email: naveens1992bmk@gmail.com

Received: 20 June 2018, Revised and Accepted: 31 December 2018

\section{ABSTRACT}

Objectives: Calocera viscosa, commonly called as the yellow stagshorn, is a jelly fungus, belongs to the family of Dacrymycetales, unknown for its medicinal properties and biological activities.

Method: The sporocarps of $C$. viscosa (Pers.) Fr. were collected from Agumbe, Karnataka. Mycochemical and Gas chromatography-mass spectroscopy (GC-MS) analysis done by standard procedures and antibacterial activity was done by agar well diffusion method.

Results: Physicochemical was analyzed and results revealed the highest percentage of alcohol-soluble extractives were present followed by ash content. Alcohol-soluble extractives were $20.76 \%$, total moisture content (10.9\%), and foreign matter (0.5\%). Extraction was done by Soxhlet apparatus using petroleum ether, chloroform, and ethanol and subjected to qualitative mycochemicals analysis both petroleum ether and chloroform extract confirms less mycochemicals, whereas ethanolic extract revealed the presence of alkaloids, tannins, flavonoids, sterols, glycosides, terpenoids, and phenols. GC-MS analysis of ethanoic extract showed many known bioactive compounds in that, 19 compounds were unknown and 21 compounds were known for its medicinal properties, most of them were food additives and flavoring agents. Antibacterial potentials were studied against pathogenic bacteria revealed that ethanolic extract showed appreciable zone of inhibition against pathogenic bacteria, in that maximum zone of inhibition showed against Klebsiella pneumonia followed by Escherichia coli and Staphylococcus aureus.

Conclusion: $C$. viscosa (Pers.) Fr. sporocarp can be explored for potential antibacterial with rich full of useful mycochemicals.

Keywords: Calocera viscosa (Pers.) Fr., Preliminary mycochemical analysis, Gas chromatography-mass spectroscopy analysis, Antimicrobial activity, Agumbe.

(C) 2019 The Authors. Published by Innovare Academic Sciences Pvt Ltd. This is an open access article under the CC BY license (http://creativecommons. org/licenses/by/4. 0/) DOI: http://dx.doi.org/10.22159/ajpcr.2019.v12i3.27997

\section{INTRODUCTION}

C. viscosa, is a jelly fungus commonly called as yellow stagshorn, belongs to Dacrymycetales. It has bright orange, yellow, or white branching basidiocarps, has yellow gelatinous in texture and slimy in appearance. It is relatively large compared to other jelly fungi reach up to $10-11 \mathrm{~cm}$ in height. It commonly grows on decaying wood, especially in coniferous wood, characteristically stumps, and roots. It is most commonly seen in autumn. It is not poisonous, but due to its tough gelatinous texture and characterless flavor and odor make it as an unpleasant to eat. Its striking color has led to it being used as a garnish on occasion.

\section{METHODOLOGY}

\section{Collection and authentication}

Sporocarp of $C$. viscosa (Pers.) Fr. collected from Agumbe, Shivamogga district, Karnataka between August and October 2017 (Fig. 1). Collected samples were studied for their morphological and anatomical characters. Classical taxonomy was followed for the identification [1].

\section{Determination of Foreign Matter}

About $1 \mathrm{~g}$ of sporocarp sample was weighed and foreign matter was carefully separated. The matter contradictory in color and texture was considered as foreign. The separated matter was weighed and subtracted from $1 \mathrm{~g}$ and percentage was calculated.

\section{Determination of moisture content}

About $1 \mathrm{~g}$ of sporocarp was weighed, powdered, and dried at $80^{\circ} \mathrm{C}$ for $24 \mathrm{~h}$ in hot air oven. After 24-26 h, the powder was weighed once more and the difference in the weight was calculated the actual percentage of moisture present in it.

\section{Determination of $\mathbf{p H}$}

Nearly $5 \%$ (w/v) (5 g in $100 \mathrm{ml}$ of water) of powdered $C$. viscosa (Pers.) Fr. sporocarp was kept in a conical flask on shaker for $5 \mathrm{~h}$ with $140 \mathrm{rpm}$ and filtered. The filtrate was analyzed for the $\mathrm{pH}$ using $\mathrm{pH}$ meter [2].

Determination of water-soluble and alcohol-soluble extractive About $5 \mathrm{~g}$ of powdered C. viscosa (Pers.) Fr. sporocarp was taken in a $100 \mathrm{ml}$ conical flask. 25-30 ml of distilled water was added and kept on a rotatory shaker (140 rpm) for 24-26 h. After that, it was filtered and dried in hot air oven at $80-85^{\circ} \mathrm{C}$ for $24 \mathrm{~h}$ and weighed another time. The difference in weight was determined and percentage of water-soluble extractive was calculated. Alcohol-soluble extractives were estimated with the same procedure but different solvents.

\section{Determination of total ash content}

A clean and dry silica crucible was weighed. $10 \mathrm{~g}$ of powdered C. viscosa (Pers.) Fr. sporocarp was taken and kept in muffle furnace and heated up to $300-350^{\circ} \mathrm{C}$ for $3-4.5 \mathrm{~h}$ until the entire powder turns into ash. The crucible was cooled and weighed again. The difference in the weight gives the total ash content $[3,4]$

\section{Determination of water-soluble ash and acid-insoluble ash}

About $1 \mathrm{~g}$ of powdered $C$. viscosa (Pers.) Fr. sporocarp was added to a dry and clean conical flask containing 10-15 ml of distilled water. The mixture was kept on a shaker with $140 \mathrm{rpm}$ for 7-8 $\mathrm{h}$ and filtered through ashless filter paper. The residue remained in the paper was kept in a crucible (silica) and subjected to muffle furnace for 3-4.5 h. The weight of ash obtained gives the percent of water-soluble ash was determined. Acid-insoluble ash was determined using same procedure using sulfuric acid or nitric acid [5]. 
Preparation of extracts

The sporocarp of $C$. viscosa (Pers.) Fr. was shade dried and occasionally blotted to remove moisture content for 20-30 days. The completely dried sporocarp of $C$. viscosa (Pers.) Fr. was grinded manually to make coarse powder. $700 \mathrm{~g}$ of material was subjected to Soxhlet extraction [5] for 24-36 h for each solvent. Organic solvents such as petroleum ether, chloroform and ethanol used successively, based on their polarity. The dissolved extracts were concentrated under reduced pressure in a rotatory evaporator before being transferred to Petri dishes for complete evaporation. Each extract was subjected to mycochemical investigation [6], to study the presence of the following constituents: Alkaloid, flavonoids, glycosides, saponins, steroids, tannins, and phenols.

\section{Antibacterial assay}

The antibacterial activity of the crude extracts was studied using agar well diffusion method $[7,8]$, comparatively with that of control dimethyl sulfoxide (DMSO), standard drug, namely ciprofloxacin, against some of the pathogenic bacteria

\section{Microorganisms used}

The extracts were tested against pathogenic bacterial strains such as Xanthomonas campestris (MTCC-2286), Pseudomonas syringae (MTCC1604), Klebsiella pneumoniae (MTCC-7028), E. coli (MTCC 1559), Salmonella typhi (MTCC-734), Pseudomonas aeruginosa (MTCC-1934), and Staphylococcus aureus (MTCC-902) obtained from microbial type culture collection and gene bank, Institution of microbial technology IMTECH Chandigarh, India. The pure cultures were subcultured in Nutrient agar media (NA media) and then used for the array.

\section{Composition of Nutrient agar media}

\begin{tabular}{ll}
\hline Beef extract & $\mathbf{3 . 0 0} \mathbf{g}$ \\
\hline Peptone & $5 \mathrm{~g}$ \\
Sodium chloride $(\mathrm{NaCl})$ & $5 \mathrm{~g}$ \\
Agar & $15 \mathrm{~g}$ \\
Distilled water & $1000 \mathrm{ml}$ \\
$\mathrm{pH}$ & 7.4 \\
\hline
\end{tabular}

\section{Preparation of media}

Nutrient agar was prepared by adding $3 \mathrm{~g}$ of beef extract, $5 \mathrm{gm}$ of sodium chloride, and $15 \mathrm{~g}$ of agar dissolved in $1000 \mathrm{ml}$ of distilled water, and $\mathrm{pH}$ of the solution was adjusted to 7.4 and then sterilized for $15 \mathrm{~min}$ at $15 \mathrm{lbs}$ pressure in an autoclave.

\section{Preparation of subcultures}

One day before the experiment, the microorganisms were inoculated into the sterilized tubes containing nutrient broth and incubated at $350^{\circ} \mathrm{C}$ for $24 \mathrm{~h}$

\section{Sterilization of media and glassware}

The media used in the present study are Nutrient agar and Nutrient broth, were sterilized in conical flask of suitable capacity of autoclaving at $15 \mathrm{lbs}$ pressure for about $20 \mathrm{~min}$. The cork borer, Petri dishes, test tubes, and pipettes were sterilized in hot air oven at $1600^{\circ} \mathrm{C}$ for an hour in rotary shaker.

\section{Antibacterial assay of extracts by agar well diffusion method}

The agar well diffusion method has been employed. $20 \mathrm{ml}$ of sterilized nutrient agar was poured uniformly in Petri plates and allowed to solidify, and then, $100 \mathrm{ml}$ of suspension of the test organisms was spread evenly on the medium with sterilized L-shaped glass spreader to get a uniform lawn of bacteria. Later, the wells were prepared with the help of clean and sterilized cork borer of $6 \mathrm{~mm}$ diameter. Three wells were punched at the four corners of the plate. The different solvent extracts of $C$. viscosa (Pers.) Fr. were loaded to the wells by $100 \mathrm{ml}$ micropipette in three different concentrations, namely 25\%, $50 \%$, and $100 \%$ respectively, which were prepared with $10 \%$ DMSO. The test was carried out by triplicates for each solvent extracts for each test organisms. All the plates were incubated at $350^{\circ} \mathrm{C}$ for $24 \mathrm{~h}$, in the Bio-Oxygen Demand incubators to favor the complete growth of the test organisms. The antibacterial activity was determined by recording zone of inhibition around well, ciprofloxacin $(1 \mathrm{mg} / \mathrm{ml}$ of sterile distilled water) was used, standard extracts were loaded after the inoculation in different concentrations, namely $25 \%, 50 \%$, and $100 \%$ respectively, which are prepared with $10 \%$ DMSO. The test was carried out by triplicates for each solvent extracts for each test organisms. All the plates were incubated at $350^{\circ} \mathrm{C}$ for $24 \mathrm{~h}$. The antibacterial activity was determined by measuring zone of inhibition around the well.

\section{RESULTS}

C. viscosa (Pers.) Fr. fruiting bodies: $5-10 \mathrm{~cm}$ tall, yellow when moist, orange-yellow when dry, variable in shape, upper branches often forked, smooth. Flesh: Yellow and gelatinous and rubbery, it does not break apart like other coral fungi (Fig. 2)

Kingdom: Fungi.

Phylum: Basidiomycota.

Subphylum: Agaricomycotina

Class: Agaricomycetes.

Subclass: Agaricomycetidae.

Order: Dacrymycetales.

Family: Dacrymycetaceae.

Genus: Calocera.

Species: C. viscosa (Pers.) Fr.

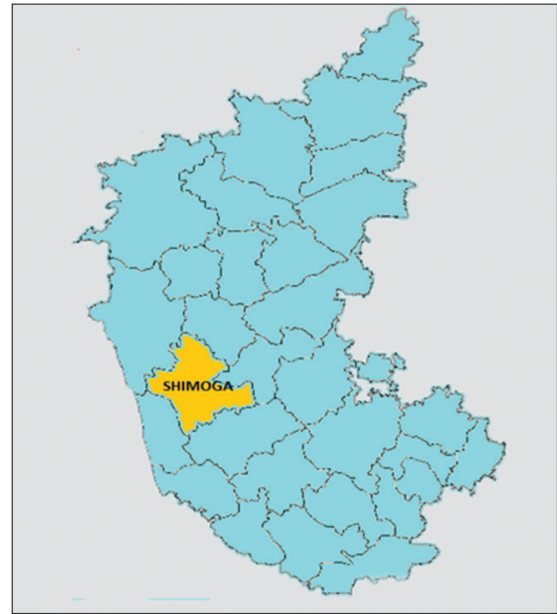

Figure 1: Location where Calocera viscosa (Pers.) Fr. sporocarp was collected

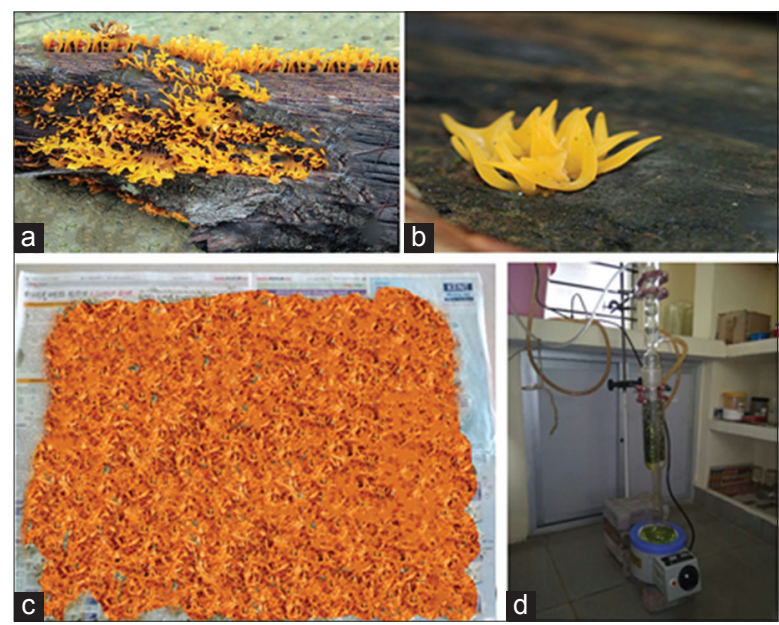

Figure 2: Calocera viscoca (Pers.) Fr. (a) Sporocarp, (b) single sporocarp, (c) dried sample, (d) Soxhlet extraction 
Physicochemical analysis of $\boldsymbol{C}$. viscosa (Pers.) Fr. sporocarp

Physicochemical analysis (Table 1) revealed that sample was found to contain high percentage of alcohol-soluble extractives (20.76\%), followed by water-soluble extractive (15.11\%), moisture content little high $(10.9 \%)$, and total ash percentage is $6.24 \%$ in that it has more water-soluble ash (67\%) followed by acid-soluble ash (33\%). $\mathrm{pH}$ of the sporocarp is little basic but nearer to the neutral value and has little foreign matter $(0.5 \%)$.

Extracts yield of $C$. viscosa (Pers.) Fr. sporocarp with different solvent

Soxhlet extraction of C. viscosa (Pers.) Fr. sporocarp (700 g) with petroleum ether $9.4 \mathrm{~g}$, chloroform $14.2 \mathrm{~g}$, and ethanol gives $56.80 \mathrm{~g}$ yield.

Preliminary qualitative mycochemical analysis of $C$. viscosa (Pers.) Fr. sporocarp extracts

The preliminary mycochemical analysis of extracts was given in Table 2. The preliminary mycochemical analysis of petroleum ether confirms the presence of alkaloids, in chloroform extracts tannins and glycosides and the ethanolic extract give positive result for alkaloids, saponins, flavonoids, glycosides, steroids, and sterols.

Hence, maximum confirmation was found in ethanol so we took ethanolic extract for further pharmacological studies.

Antibacterial activity of the sporocarp ethanolic extract of C. viscosa (Pers.) Fr. against some pathogenic bacterial strains

In antibacterial activity, $C$. viscosa (Pers.) Fr. ethanolic extract showed concentration-dependent zone of inhibition against tested bacterial pathogens, Maximum zone of inhibition showed by $K$. pneumonia $(17 \pm 0.42)$ followed by $E$. coli $(15 \pm 0.31)$ and $S$. aureus $(15 \pm 0.36)$ and the least zone of inhibition showed by P. aeruginosa (12 \pm 0.22$)$. All

Table 1: Physicochemical analysis of Calocera viscosa (Pers.) Fr. sporocarp

\begin{tabular}{lll}
\hline Sl. no. & Parameters & $\begin{array}{l}\text { Quantity in } \\
\text { percentage (\%) }\end{array}$ \\
\hline 1 & Foreign matter & 0.5 \\
2 & Moisture content & 10.9 \\
3 & Water-soluble extractive & 15.11 \\
4 & Alcohol-soluble extractive & 20.76 \\
5 & pH of 5\% w/v solution of aqueous extract & 6.92 \\
6 & Total ash content & 6.24 \\
7 & Water-soluble ash & 67 \\
8 & Acid-soluble ash & 33 \\
\hline
\end{tabular}

the values obtained from the experiment were triplicated and values were expressed in mean \pm standard error of mean. Zone of inhibition is measured in millimeters (Table 3 and Fig. 4).

Quantitative Gas chromatography-mass spectroscopy (GC-MS) analysis of $C$. viscosa (Pers.) Fr. sporocarp ethanolic extract We took only ethanolic extract of C. viscosa (Pers.) Fr. for GC-MS analysis due to less metabolite in the other two extracts (Table 4 and Figs. 5 and 6).

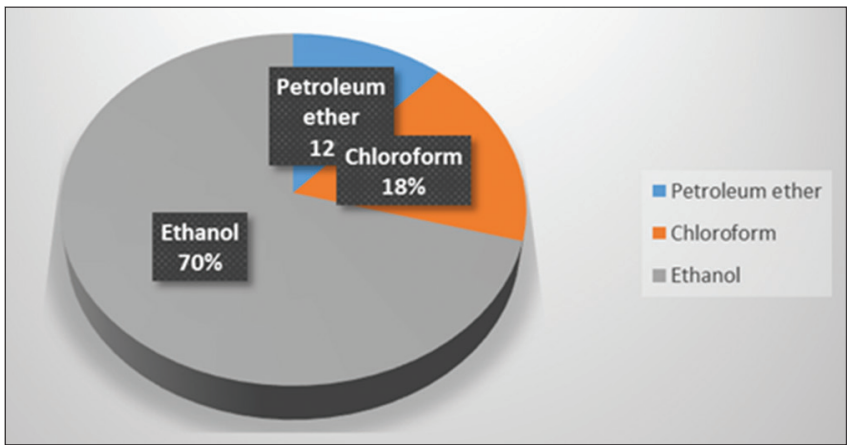

Figure 3: Extracts yield of Calocera viscosa (Pers.) Fr. sporocarp with different solvent

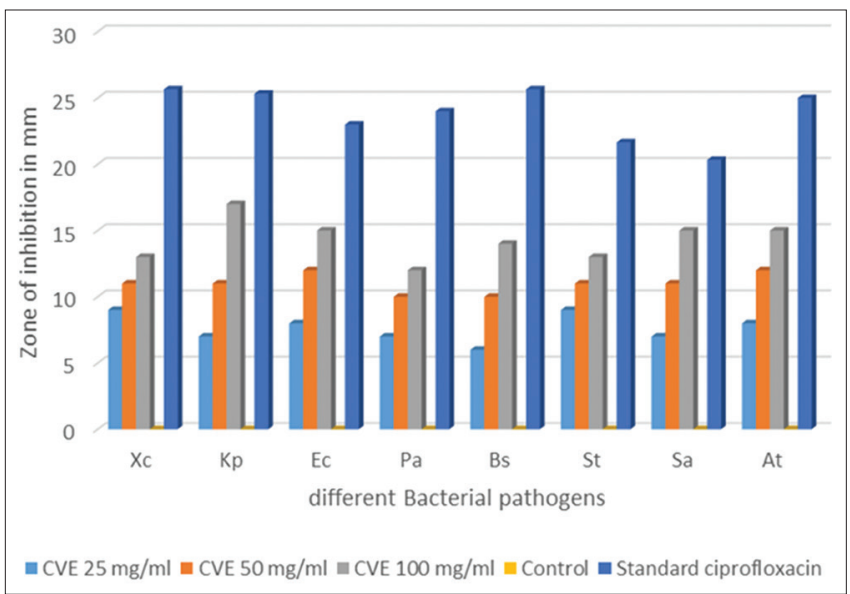

Figure 4: Antibacterial activity of the sporocarp ethanolic extract of Calocera viscosa (Pers.) Fr. against some pathogenic bacterial strains. CVE - C. viscosa (Pers.) Fr. ethanolic extract

Table 2: Preliminary qualitative mycochemical analysis of Calocera viscosa (Pers.) Fr. sporocarp extracts

\begin{tabular}{|c|c|c|c|c|c|}
\hline Sl. No. & Secondary metabolites & Name of the test & Pet ether & Chloroform & Ethanolic \\
\hline \multirow[t]{2}{*}{1} & Alkaloids & Mayer's test & + & - & + \\
\hline & & Wagner's test & + & - & + \\
\hline 2 & Saponins & Foam test & - & - & + \\
\hline \multirow[t]{3}{*}{3} & Tannins & Ferric chloride test & - & + & - \\
\hline & & Gelatin test & - & + & - \\
\hline & & Shenoda test & - & + & - \\
\hline \multirow[t]{3}{*}{4} & Flavonoids & Zinc $\mathrm{HCl}$ reduction test & - & - & + \\
\hline & & Lead acetate test & - & - & + \\
\hline & & Ferric chloride test & - & - & + \\
\hline 5 & Steroids & Salkowski test & - & - & + \\
\hline \multirow[t]{3}{*}{6} & Glycosides & Legal's test & - & + & - \\
\hline & & Brown water test & - & + & + \\
\hline & & Keller-Kiliani test & - & + & - \\
\hline 7 & Phenols & Ellagic acid test & - & - & - \\
\hline 8 & Sterols & Liebermann-Burchard test & - & - & + \\
\hline
\end{tabular}

+: Positive result, -: Negative results 
Table 3: Antibacterial activity of the sporocarp ethanolic extract of Calocera viscosa (Pers.) Fr. against some pathogenic bacterial strains

\begin{tabular}{|c|c|c|c|c|c|}
\hline \multirow{2}{*}{$\begin{array}{l}\text { Test } \\
\text { Organisms }\end{array}$} & \multicolumn{5}{|c|}{ Zone of inhibition in $\mathrm{mm}$} \\
\hline & $25 \mathrm{mg} / \mathrm{ml}$ & $50 \mathrm{mg} / \mathrm{ml}$ & $100 \mathrm{mg} / \mathrm{ml}$ & Control & Standard \\
\hline$X c$ & $9 \pm 0.26$ & $11 \pm 0.55$ & $13 \pm 0.32$ & $0 \pm 0$ & $25.66 \pm 0.23$ \\
\hline$K p$ & $7 \pm 0.32$ & $11 \pm 0.23$ & $17 \pm 0.42$ & $0 \pm 0$ & $25.33 \pm 0.54$ \\
\hline$E c$ & $8 \pm 0.42$ & $12 \pm 0.54$ & $15 \pm 0.31$ & $0 \pm 0$ & $23 \pm 0.21$ \\
\hline $\mathrm{Pa}$ & $7 \pm 0.31$ & $10 \pm 0.21$ & $12 \pm 0.22$ & $0 \pm 0$ & $24 \pm 0.43$ \\
\hline Ps & $6 \pm 0.22$ & $10 \pm 0.43$ & $14 \pm 0.31$ & $0 \pm 0$ & $25.66 \pm 0.21$ \\
\hline St & $9 \pm 0.36$ & $11 \pm 0.35$ & $13 \pm 0.22$ & $0 \pm 0$ & $21.66 \pm 0.43$ \\
\hline$S a$ & $7 \pm 0.55$ & $11 \pm 0.37$ & $15 \pm 0.36$ & $0 \pm 0$ & $20.33 \pm 0.35$ \\
\hline
\end{tabular}

Xc: Xanthomonas campestris, Kp: Klebsiella pneumoniae, Ec: Escherichia coli, Pa: Pseudomonas aeruginosa, Ps: Pseudomonas syringae, St: Salmonella typhi,

Sa: Staphylococcus aureus

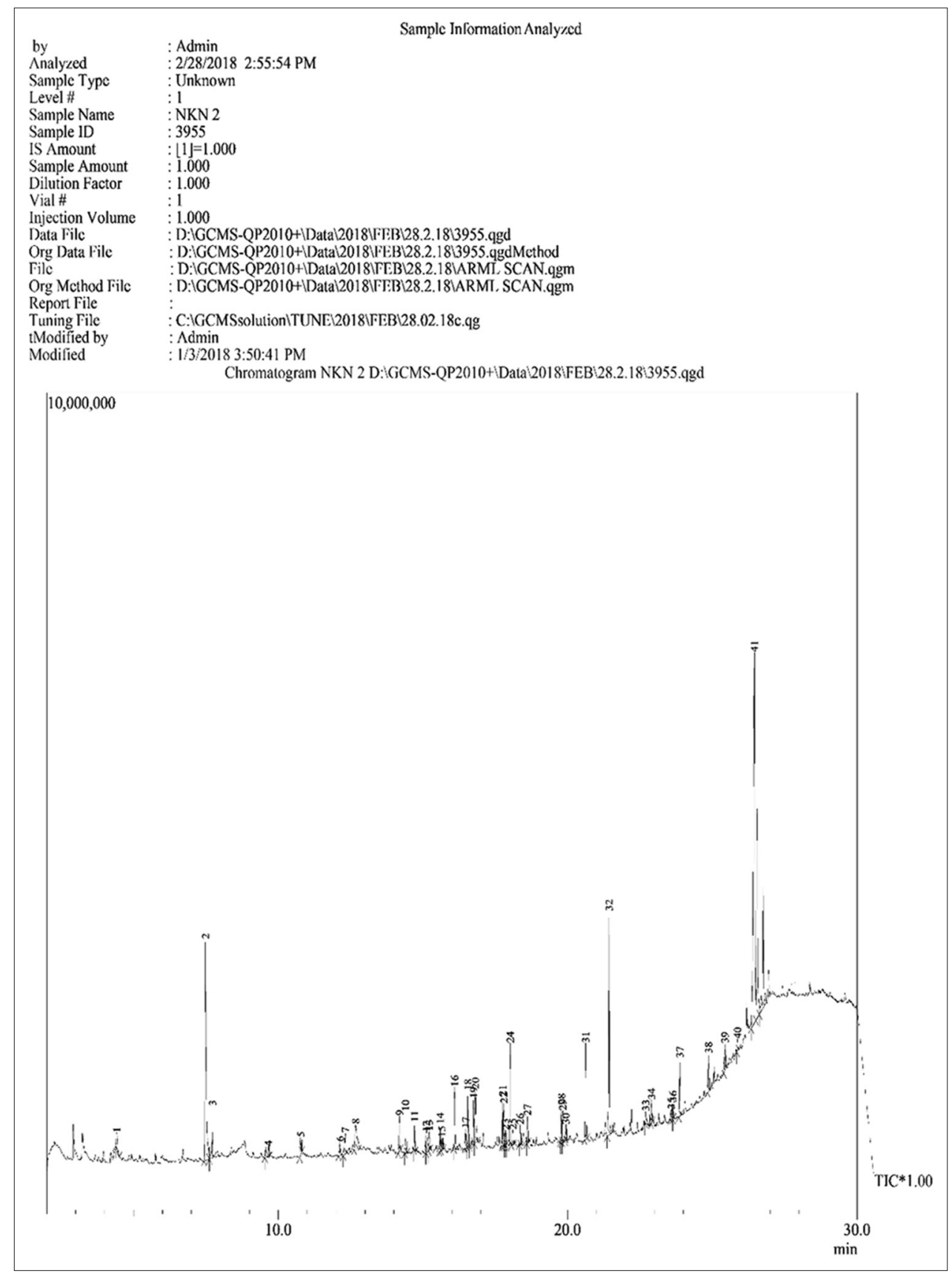

Figure 5: Gas chromatography-mass spectroscopy analysis of the sporocarp ethanolic extract of Calocera viscosa (Pers.) Fr.

GC-MS analysis C. viscosa (Pers.) Fr. ethanolic extract confirms the presence of 40 compounds, of these 19 compounds were unknown and
21 compounds were known for its medicinal properties, most of them were flavoring agents and food additives (11 compounds), followed by 
Table 4: Gas chromatography-mass spectroscopy analysis of Calocera viscosa (Pers.) Fr. sporocarp ethanolic extract

\begin{tabular}{|c|c|c|c|}
\hline Sl. no & $\begin{array}{l}\text { Percentage in } \\
\text { crude extract }\end{array}$ & Chemical name & Properties \\
\hline 1 & 0.90 & 1,2,3-Propanetriol (CAS) glycerol & $\begin{array}{l}\text { Used as a solvent, emollient, pharmaceutical agent, or } \\
\text { sweetening agent, humectant, solvent, preservative, } \\
\text { thickening agent, flavoring agent, an osmotic laxative } \\
\text { osmotic diuretic [9] }\end{array}$ \\
\hline 2 & 10.72 & 1,2-benzenediol & $\begin{array}{l}\text { Precursors to pesticides, flavors, and fragrances. } \\
\text { Small amounts of catechol occur naturally in fruits } \\
\text { and vegetables used as flavoring agents, dyes, used } \\
\text { as a photographic developer, a developer for fur dyes, } \\
\text { as an intermediate for antioxidants in rubber and } \\
\text { lubricating oils, in polymerization inhibitors, and in } \\
\text { pharmaceuticals [10] }\end{array}$ \\
\hline 3 & 1.09 & 2,3-dihydro-Benzofuran & Moderately toxic $[11]$ \\
\hline 4 & 0.67 & Decanoic acid (CAS) capric acid & $\begin{array}{l}\text { Found naturally in the coconut and palm kernel oils as } \\
\text { well as the milk of various mammals. Used in organic } \\
\text { synthesis, insecticide, Acaricide, Herbicide, used also } \\
\text { as plant growth regulator, flavoring agent, perfume } \\
\text { manufacturing, medicine, lubricating grease, rubber, and } \\
\text { dye. Antifungal agent, surfactant [12] }\end{array}$ \\
\hline 5 & 0.64 & Benzaldehyde, 2-hydroxy-6-methyl- & Unknown \\
\hline 6 & 0.47 & Dodecanoic acid (CAS) lauric acid & $\begin{array}{l}\text { Found naturally in various plant and animal fats and } \\
\text { oils and is a major component of coconut oil and palm } \\
\text { kernel oil. Flavoring agents, surfactants, dyes, insecticide, } \\
\text { acaricide, herbicide, plant growth regulator antimicrobial } \\
\text { properties, used in many soaps and shampoos [13] }\end{array}$ \\
\hline 7 & 1.10 & Benzoic acid, 4-hydroxy-3-methoxy- (CAS) Vanillic acid & $\begin{array}{l}\text { Found naturally in vanilla and many other plant extracts } \\
\text { flavoring and scent agent that produces a pleasant, } \\
\text { creamy odor, has anti-inflammatory activity [14] }\end{array}$ \\
\hline 8 & 2.35 & 2-Methoxy-5-formyl-1,3 (2H)-benzoxodiole & Unknown \\
\hline 9 & 1.25 & 1-(4-Hydroxybenzylidene) acetone & Unknown \\
\hline 10 & 0.53 & Tetradecanoic acid & $\begin{array}{l}\text { Naturally occurs in most animal and vegetable fats, } \\
\text { particularly butterfat and coconut, palm, and nutmeg } \\
\text { oils. It is used to synthesize flavor and as an ingredient in } \\
\text { soaps and cosmetics [15] }\end{array}$ \\
\hline 11 & 0.68 & E-15-Heptadecenal & Unknown \\
\hline 12 & 1.30 & Phosphonofluoridic acid, (1-methylethyl)-, hexyl ester & Unknown \\
\hline 13 & 0.55 & 3,7,11,15-Tetramethyl-2-hexadecen-1-ol & $\begin{array}{l}\text { A constituent of chlorophyll. Mycol is commonly used } \\
\text { as a precursor for the manufacture of synthetic forms of } \\
\text { Vitamin E and Vitamin K1. Flavoring agents [16] }\end{array}$ \\
\hline 14 & 0.79 & 8-Octadecanone & Unknown \\
\hline 15 & 0.40 & 1-Eicosanol & $\begin{array}{l}\text { Has been detected in multiple biofluids, such as saliva } \\
\text { and urine. Emollients [17] }\end{array}$ \\
\hline 16 & 1.78 & $\begin{array}{l}\text { Eicosanoic acid, methyl ester (CAS) Arachidic acid methyl } \\
\text { ester }\end{array}$ & Unknown \\
\hline 17 & 0.79 & 9-Octadecenoic acid (Z)- (CAS) Oleic acid & $\begin{array}{l}\text { Oleic acid is used commercially in the preparation of } \\
\text { oleates and lotions, and as a pharmaceutical solvent, } \\
\text { major constituent of plant oils, for example, olive } \\
\text { oil, almond oil. Food additive. Oleic acid is used in } \\
\text { manufacturing of surfactants, soaps, plasticizers. } \\
\text { Emulsifying agent in foods and pharmaceuticals, skin } \\
\text { penetrant. Herbicide, insecticide, fungicide [18] }\end{array}$ \\
\hline 18 & 1.61 & 1,2-Benzenedicarboxylic acid, butyl 2-ethylhexyl ester & Unknown \\
\hline 19 & 1.59 & 1-Nonadecene & Unknown \\
\hline 20 & 3.01 & 3-(p-hydroxy-m-methoxyphenyl)-2-propenal & Unknown \\
\hline 21 & 1.32 & $\begin{array}{l}\text { 9,12-Octadecadienoic acid (Z, Z)-, methyl ester (CAS) } \\
\text { Methyl linoleate }\end{array}$ & $\begin{array}{l}\text { Methyl linoleate is found in cloves. It is part of a mixture } \\
\text { with methyl linolenate which is used as a flavoring } \\
\text { ingredient. Dairy flavoring agent [19] }\end{array}$ \\
\hline 22 & 1.07 & $\begin{array}{l}\text { 9-Octadecenoic acid, methyl ester, (E)- (CAS) Methyl } \\
\text { elaidate }\end{array}$ & Unknown \\
\hline 23 & 0.45 & $\begin{array}{l}\text { Cyclopentaneundecanoic acid, methyl ester (CAS) Methyl } \\
\text { 11-Cyclopent }\end{array}$ & Unknown \\
\hline 24 & 2.64 & Octadecanoic acid, methyl ester (CAS) Methyl stearate & $\begin{array}{l}\text { Flavoring agents, found in cloves, lubricants, and } \\
\text { lubricant additives [20] }\end{array}$ \\
\hline 25 & 0.42 & Dihydropyranno (3,2-G) Chromanne & Unknown \\
\hline
\end{tabular}


Table 4: (Continued)

\begin{tabular}{|c|c|c|c|}
\hline Sl. no & $\begin{array}{l}\text { Percentage in } \\
\text { crude extract }\end{array}$ & Chemical name & Properties \\
\hline 26 & 0.50 & $\begin{array}{l}\text { Cyclopropaneoctanoic acid, 2-[[2-[(2-ethylcyclopropyl) } \\
\text { methyl] cyclopropyl] me }\end{array}$ & Unknown \\
\hline 27 & 0.83 & Ethyl Ester Of Docosanoic Acid & Unknown \\
\hline 28 & 7.21 & Octadecanal (CAS) Stearaldehyde & $\begin{array}{l}\text { Octadecanal is often used as the substrate of choice } \\
\text { to test FALDH activity in patients suspected of having } \\
\text { Sjogren-Larsson syndrome [21] }\end{array}$ \\
\hline 29 & 0.90 & 2-Propenoic acid, 3-(4-methoxyphenyl)-, 2-ethylhexyl ester & $\begin{array}{l}\text { Octinoxate is a cinnamate ester and common ingredient } \\
\text { in sunscreen and other skin care products to minimize } \\
\text { DNA photodamage. It is used in pharmaceutical and } \\
\text { cosmetic formulations [22] }\end{array}$ \\
\hline 30 & 0.43 & Cyclohexane, eicosyl- & Unknown \\
\hline 31 & 2.75 & Hexadecanal & $\begin{array}{l}\text { Found in a number of food items such as avocado, } \\
\text { giant butterbur, herbs and spices, and enokitake, which } \\
\text { makes palmitaldehyde a potential biomarker for the } \\
\text { consumption of these food products. Used as flavoring } \\
\text { agents, palmitaldehyde is also involved in few metabolic } \\
\text { disorders, which include Fabry disease, Gaucher disease, } \\
\text { and Krabbe disease [23] }\end{array}$ \\
\hline 32 & 0.58 & 9-Octadecenoic acid (Z)-, 2,3-dihydroxypropyl ester & $\begin{array}{l}\text { Used commercially in the preparation of oleates and } \\
\text { lotions, and as a pharmaceutical solvent [24] }\end{array}$ \\
\hline 33 & 0.57 & Tetracosanoic acid, methyl ester & Unknown \\
\hline 34 & 0.49 & Tetraethylene glycol monododecyl ether & $\begin{array}{l}\text { Growth inhibition of HIV1 3B infected human MOLT4 } \\
\text { cells after } 5 \text { days by MTT assay [25] }\end{array}$ \\
\hline 35 & 24.11 & Ergosterol & $\begin{array}{l}\text { Ergosterol is a steroid occurring in fungi, precursor forms } \\
\text { of vitamins, anti-inflammatory activity, antiprotozoal } \\
\text { drug [26] }\end{array}$ \\
\hline 36 & 12.54 & Ergost-5,8 (14)-dien-3-ol & Unknown \\
\hline 37 & 5.05 & 7,22-Ergostadienone & Unknown \\
\hline 38 & 1.83 & beta.-SitosterolC & $\begin{array}{l}\text { Found in vegetable oil, nuts, avocados and prepared } \\
\text { foods, potential to reduce BPH and blood cholesterol } \\
\text { levels, used to treat hyperlipidemias, cytotoxicity against } \\
\text { human MCF7 cells by MTT assay [27] }\end{array}$ \\
\hline 39 & 1.41 & 10,13-dimethyl-17-(1,4,5-trimethyl-hex-2-enyl)-1,2,9,10,11 & Unknown \\
\hline 40 & 1.68 & 16-Hentriacontanone (CAS) palmitone & $\begin{array}{l}\text { Found in herbs and spices, pepper (spice), and potato, } \\
\text { which makes palmitone a potential biomarker for the } \\
\text { consumption of these food products. Palmitone is found } \\
\text { in herbs and spices. Palmitone is a constituent of Piper } \\
\text { nigrum [28] }\end{array}$ \\
\hline
\end{tabular}

BPH: Benign prostatic hyperplasia

Table 5: Extracts yield of Calocera viscosa (Pers.) Fr. sporocarp with different solvent

\begin{tabular}{lll}
\hline Sl. No. & Solvent used & Extract yield in grams \\
\hline 1 & Petroleum ether & 9.4 \\
2 & Chloroform & 14.2 \\
3 & Ethanol & 56.8 \\
\hline
\end{tabular}

three insecticidal, three acricidal, three fungicidal, one antioxidant, one antimicrobial, and one pesticidal rest of them were antiviral, lubricant, etc., in that the compound named tetraethylene glycol monododecyl ether $(0.49 \%)$ has reported for the inhibition of HIV1 3B-infected human MOLT4 cells after 5 days by MTT assay (Table 3).

Major percentage of compound is ergosterol(24.11\%), a naturally occurring steroid in fungi, precursor forms of many vitamins, has anti-inflammatory activity followed by ergost-5,8(14)-dien-3-ol (12.54\%) has unknown properties and 1,2-benzenediol (10.72\%) precursors to pesticides, flavors, and fragrances. Catechol occur naturally in fruits and vegetables in smaller percentage but in macrofungi its rare which is used as flavoring agents, dyes, pharmaceutical agents. Catechol also used in rubber and lubriccating oils as an intermediate for antioxidants. 1-eicosanol (0.4\%) present in least percentage in the methanolic extract which is naturally occurs in bio fluids, such as saliva and urine, used in the preparation of emollients.

\section{DISCUSSION}

Physicochemical analysis of $C$. viscosa (Pers.) Fr. sporocarp Physicochemical analysis (Table 1) it is confirmed that sample was found to contain high percentage of alcohol-soluble extractives $(20.76 \%)$ than the water-soluble extractive $(15.11 \%)$, C. viscosa sporocarp is succulent so moisture content little high (10.9\%), and has more water-soluble ash (67\%) than the acid-soluble ash (33\%). pH of the sporocarp is little basic but nearer to the neutral value due to its succulent behavior.

\section{Soxhlet extraction of $C$. viscosa (Pers.) Fr. sporocarp}

Soxhlet extraction is a common procedure to extract phytoconstituents which is essential to humankind. The aerial part sample $(700 \mathrm{~g})$ of C. viscosa (Pers.) Fr. sporocarp yields maximum percentage of extract in ethanolic extract $(56.80 \mathrm{~g})$, so it is revealed that $C$. viscosa (Pers.) Fr. sporocarp sample is having more alcohol-soluble extractive which is more essential in extraction of good microconstituent (Table 5 and Fig. 3).

The preliminary mycochemical analysis of C. viscosa (Pers.) Fr. sporocarp extract

The preliminary mycochemical analysis of C. viscosa (Pers.) Fr. sporocarp extracts revealed the presence of more microconstituent in the ethanolic extracts such as alkaloids, saponins, flavonoids, 


\begin{tabular}{|c|c|c|c|c|c|}
\hline \multicolumn{6}{|r|}{ Peak Report TIC } \\
\hline Peak\# & R.Time & l.Time & F.Time & Area & Area\% Name \\
\hline & 4.418 & 4.383 & 4.508 & 655544 & 0.90 1,2,3-Propanetriol (CAS) Glycerol \\
\hline 2 & 7.484 & 7.433 & 7.617 & 7843667 & $10.721,2$-Benzenediol \\
\hline 3 & 7.723 & 7.617 & 7.767 & 799274 & 1.09 2.3-DIHYDRO-BENZOFURAN \\
\hline 4 & 9.657 & 9.533 & 9.692 & 492442 & 0.67 Decanoic acid (CAS) Capric acid \\
\hline 5 & 10.774 & 10.742 & 10.817 & 471592 & 0.64 Benzaldehyde, 2 -hydroxy-6-methyl- \\
\hline 6 & 12.135 & 12.083 & 12.167 & 342467 & 0.47 Dodecanoic acid (CAS) Lauric acid \\
\hline 7 & 12.318 & 12.242 & 12.367 & 804693 & 1.10 Benzoic acid, 4-hydroxy-3-methoxy-(CAS) Vanillic acid \\
\hline 8 & 12.675 & 12.617 & 12.783 & 1722409 & 2.35 2-Methoxy-5-formyl-1,3(2H)-benzoxodiole \\
\hline 9 & 14.191 & 14.150 & 14.233 & 916458 & 1.25 1-(4-Hydroxybenzylidene)acetone \\
\hline 10 & 14.398 & 14.367 & 14.450 & 384863 & 0.53 Tetradecanoic acid \\
\hline 11 & 14.715 & 14.683 & 14.742 & 496258 & 0.68 E-15-Heptadecenal \\
\hline 12 & 15.117 & 15.100 & 15.192 & 953172 & 1.30 Phosphonofluoridic acid, (1-methylethyl)-, hexyl ester \\
\hline 13 & 15.210 & 15.192 & 15.250 & 402978 & 0.55 3,7,11,15-Tetramethyl-2-hexadecen-1-0l \\
\hline 14 & 15.597 & 15.567 & 15.625 & 576383 & 0.79 8-Octadecanone \\
\hline 15 & 15.654 & 15.625 & 15.692 & 294084 & 0.40 l-Eicosanol \\
\hline 16 & 16.098 & 16.058 & 16.158 & 1300212 & 1.78 Eicosanoic acid, methyl ester (CAS) Arachidic acid methyl ester \\
\hline 17 & 16.475 & 16.442 & 16.525 & 578237 & 0.79 9-0ctadecenoic acid (Z)-(CAS) Oleic acid \\
\hline 18 & 16.557 & 16.525 & 16.600 & 1175933 & 1.61 1.2-Benzenedicarboxylic acid, butyl 2-ethylhexyl ester \\
\hline 19 & 16.753 & 16.600 & 16.775 & 1164491 & 1.591 -Nonadecene \\
\hline 20 & 16.813 & 16.775 & 16.900 & 2202313 & 3.01 3-(p-hydroxy-m-methoxyphenyl)-2-propenal \\
\hline 21 & 17.752 & 17.725 & 17.775 & 968349 & 1.32 9,12-Octadecadienoic acid (Z,Z)-, methyl ester (CAS) Methyl linoleate \\
\hline 22 & 17.799 & 17.775 & 17.825 & 784768 & 1.07 9-0ctadecenoic acid, methyl ester, (E)- (CAS) Methyl elaidate \\
\hline 23 & 17.848 & 17.825 & 17.875 & 327457 & 0.45 Cyclopentaneundecanoic acid, methyl ester (CAS) METHYL 11-CYCLOPENTYLUN \\
\hline 24 & 18.017 & 17.875 & 18.058 & 1931883 & 2.64 Octadecanoic acid, methyl ester (CAS) Methyl stearate \\
\hline 25 & 18.107 & 18.058 & 18.142 & 305664 & 0.42 DIHYDROPYRANNO (3,2-G) CHROMANNE \\
\hline 26 & 18.360 & 18.333 & 18.383 & 363149 & 0.50 Cyclopropaneoctanoic acid, $2-[[2-[(2-$ ethylcyclopropyl)methyl] cyclopropyl]|methyl]-, \\
\hline 27 & 18.611 & 18.583 & 18.642 & 604007 & 0.83 ETHYL ESTER OF DOCOSANOIC ACID \\
\hline 28 & 19.788 & 19.750 & 19.808 & 878216 & 1.20 Octadecanal (CAS) Stearaldehyde \\
\hline 29 & 19.829 & 19.808 & 19.867 & 659515 & 0.90 2-Propenoic acid, 3-(4-methoxyphenyl)-, 2-ethylhexyl ester \\
\hline 30 & 19.939 & 19.908 & 19.975 & 318059 & 0.43 Cyclohexane, eicosyl- \\
\hline 31 & 20.627 & 20.583 & 20.675 & 2013236 & 2.75 Hexadecanal \\
\hline 32 & 21.434 & 21.367 & 21.492 & 5127074 & 7.01 Octadecanal (CAS) Stearaldehyde \\
\hline 33 & 22.700 & 22.675 & 22.833 & 427493 & 0.589 -Octadecenoic acid (Z)-,2,3-dihydroxypropyl ester \\
\hline 34 & 22.902 & 22.883 & 22.933 & 414585 & 0.57 Tetracosanoic acid, methyl ester \\
\hline 35 & 23.583 & 23.558 & 23.625 & 355917 & 0.49 Tetraethylene glycol monododecyl ether \\
\hline 36 & 26.454 & 26.342 & 26.508 & 17646911 & 24.11 Ergosterol \\
\hline 37 & 26.551 & 26.508 & 26.625 & 9185362 & 12.54 Ergost-5,8(14)-dien-3-0l \\
\hline 38 & 26.761 & 26.625 & 26.808 & 3698822 & 5.05 7,22-Ergostadienone \\
\hline 39 & 27.171 & 27.133 & 27.217 & 1335849 & 1.83 beta-Sitosterol \\
\hline 40 & 27.684 & 27.642 & 27.733 & 1031969 & 1.41 10,13-DIMETHYL-17-(1,4,5-TRIMETHYL-HEX-2-ENYL)-1,2,9,10,11,12,13,15,16 \\
\hline 41 & 27.897 & 27.858 & 27.942 & 1229725 & 1.68 16-Hentriacontanone (CAS) Palmitone \\
\hline & & & & 73185480 & 100.00 \\
\hline
\end{tabular}

Figure 6: Gas chromatography-mass spectroscopy analysis of the sporocarp ethanolic extract of Calocera viscosa (Pers.) Fr.

glycosides, steroids, and sterols. Hence, we took only ethanolic extract for GC-MS analysis for confirmation of different constituents (Table 2).

\section{Antibacterial properties of C. viscosa (Pers.) Fr. sporocarp ethanolic extract \\ C. viscosa (Pers.) Fr. ethanolic extract showed maximum zone of inhibition for K. pneumonia causes pneumonia fever followed by E. coli common microflora and opportunistic pathogen and $S$. aureus which causes pneumonia, meningitis, osteomyelitis, endocarditis, toxic shock syndrome, bacteremia, and sepsis (Table 3 and Fig. 4).}

GC-MS analysis of $\boldsymbol{C}$. viscosa (Pers.) Fr. sporocarp ethanolic extract GC-MS analysis of $C$. viscosa (Pers.) Fr. ethanolic extract was analyzed in the instrument GC Model: Thermo trace GC ultra, MS Model: Thermo DSQ II, Ionization: Electron impact ionization, chemical ionization, and mass range: $1-1074 \mathrm{~m} / \mathrm{z}$ and obtained spectra were analyzed, 40 compounds, of these 19 compounds were unknown and 21 compounds were known for its medicinal properties, most of them were flavoring agents and food additives ( 11 compounds), followed by three insecticidal, three acricidal, three fungicidal, one antioxidant, one antimicrobial, and one pesticidal rest of them were antiviral, lubricant, etc., in that the compound named tetraethylene glycol monododecyl ether $(0.49 \%)$ has reported for inhibition of HIV1 3B-infected human MOLT4 cells (Table 4 and Figs. 5 and 6).

Major percentage of compound is ergosterol (24.11\%), a naturally occurring steroid in fungi, precursor forms of many vitamins, has antiinflammatory activity followed by ergost-5,8(14)-dien-3-ol (12.54\%) has unknown properties and 1,2-benzenediol (10.72\%) precursors to pesticides, flavors, and fragrances. Small amounts of catechol occur in the sporocarp which is naturally in fruits and vegetables used as flavoring agents, dyes, and in pharmaceuticals, Octadecanal (7.21\%) used as the indicator of Sjogren-larsson syndrome [18], hexadecanal $(2.75 \%)$ naturally occurs in many plants which is confirmed in enokitake mushroom and C. viscosa [20], beta. Sitosterol (1.83\%) used in the treatment of hyperlipidemias [24]. Moreover, the least percentage is 1-eicosanol $(0.4 \%)$ naturally occurs in biofluids, such as saliva and urine, used in the preparation of emollients. [14].

11 compounds were known as flavoring agents and food additives used in food industries such as 1,2-benzenediol, octadecanoic acid, methyl ester; hexadecanal; 9,12-octadecadienoic acid (Z,Z), methyl ester; benzoic acid, 4-hydroxy-3-methoxy-; 1,2,3-propanetriol; 3,7,11,15-tetramethyl-2-hexadecen-1-ol; tetradecanoic acid; dodecanoic acid; and 9-octadecenoic acid.

In observation, it is revealed that major compounds such as ergosterol (24.11\%) and 1,2-benzenediol (10.72\%) were reported from fungi and other minor compounds were naturally occurs in plants and animals. 10 compounds such as 1,2-benzenediol; hexadecanal; octadecanoic acid, methyl ester; beta.-Sitosterol; 16-hentriacontanone; 9,12-octadecadienoic acid (Z,Z)-, methyl ester; benzoic acid, 4-hydroxy-3-methoxy-; oleic acid; 2,3-dihydroxypropyl ester; and 3,7,11,15-tetramethyl-2-hexadecen-1-ol mainly reported from plants. Three compounds such as decanoic acid, tetradecanoic acid, and dodecanoic acid reported from plants and animals and 
1-eicosanol reported from animal in multiple biofluids such as saliva and urine.

Many edible mushrooms such as Lentinus sajor-caju (Fr.) Fr. belongs to basidiomycetous confirm the presence of amino acids such as lysine, aspartic acid, serine, threonine, glutamic acid, cysteine, glycine, alanine, valine, methionine, isoleucine, leucine, tyrosine, phenylalanine, and histidine [29]. Environmental factors affect the fruiting body development of mushrooms and also its mycochemicals[30]. Hence, by growing the mushroom in a controlled physiological conditions such as temperature, light, and media composition also improves the mycochemical quantity in the selected mushrooms.

\section{CONCLUSION}

After the present investigation, it can be concluded that $C$. viscosa (Pers.) Fr. sporocarp ethanolic extract can act as good antibacterial agent with rich full of useful mycochemicals. GC-MS analysis of ethanolic extract revealed the presence of 40 compounds in that 21 compounds were known for its medicinal properties, most of them were food additive and flavoring agents followed by antioxidant, antihypercholesterolemic, anti-inflammatory agents, etc.

The overall study on antimicrobial, GC-MS analysis reports that C. viscosa (Pers.) Fr. sporocarp species contains many active compounds which by their synergistic effect may reduce the growth of pathogenic bacteria and rich with micro constituents. Hence, it is finally concluded that C. viscosa (Pers.) Fr. sporocarp can be explored for potential antibacterial with rich full of useful mycochemicals.

\section{ACKNOWLEDGMENT}

The authors thankful to the Department of Applied Botany, Kuvempu University, Karnataka, for providing facilities to conduct our experimental work. The author also thankful to DST-SERB (EEQ/2016/000669) for providing the grant to conduct our work.

\section{AUTHORS' CONTRIBUTIONS}

Mr. Naveen Kumar Naik and Mr. Ashwathanarayana R have collected the data and conducted the experiment and Prof. Raja Naika drafted and corrected the article.

\section{CONFLICTS OF INTEREST}

None.

\section{REFERENCES}

1. Pande A. Ascomycetes of Peninsular India. India: Scientific Publisher; 2008.

2. Iqbal D, Raju K, Pawar, Rajeev KR, Sharma S. Physico-chemical standardization of Butea monosperma (Lam) Kuntze (Palasha): An Ayurveda drug. Int J Pharm Qual Assur 2010;2:49-51.

3. Gupta AK. Quality Standards of Indian Medicinal Plants. India: Indian Council of Medicinal Research; 2003.

4. Indrayan AK, Sharma S. Durgapal D. Kumar N, Kumar M. Valued plants from Uttaranchal. Curr Sci 2005;89:1252-5.

5. Ahmad RV, Sharma RK. Proceedings of WHO Training CumWorkshop, Evaluation of Drug for Standardization. Pharmaceutical lab for Indian Medicine, Ministry of Health and Family Welfare. Ghaziabad: Government of India; 2001.

6. De-Castro MD, Ayuso LE. Soxhlet extraction of solid materials: An outdated technique with a promising innovative future. Anal Chim Acta 1998;369:1-10.

7. Harborne JB. Mycochemical Methods: A Guide to Modern Techniques of Plant Analysis. $3^{\text {rd }}$ ed. New York: Chapman and Hall Co.; 1998. p. 1-302.

8. Irshad S, Mahmood M, Perveen F. In-vitro anti-bacterial activities of three medicinal plants using agar well diffusion method. Res J Biol 2012;2:1-8.

9. PubChem Glycerin $\mathrm{C}_{3} \mathrm{H}_{8} \mathrm{O}_{3}$. Available from: https://www.pubchem. ncbi.nlm.nih.gov/compound/glycerol.

10. PubChem Pyrocatechol $\mathrm{C}_{6} \mathrm{H}_{6} \mathrm{O}_{2}$. Available from: https://www.pubchem. ncbi.nlm.nih.gov/compound/catechol.

11. PubChem Coumaran $\mathrm{C}_{8} \mathrm{H}_{8} \mathrm{O}$. Available from: https://www.pubchem. ncbi.nlm.nih.gov/compound/2 3-dihydrobenzofuran.

12. PubChem Capric Acid $\mathrm{C}_{10} \bar{H}_{20} \mathrm{O}_{2}$. Available from: https://www. pubchem.ncbi.nlm.nih.gov/compound/Decanoic acid.

13. PubChem Lauric Acid $\mathrm{C}_{12} \mathrm{H}_{24} \mathrm{O}_{2}$. Available from: $\bar{h}$ ttps://www.pubchem. ncbi.nlm.nih.gov/compound/lauric_acid.

14. PubChem Vanillic Acid $\mathrm{C}_{8} \mathrm{H}_{8} \mathrm{O}_{4}$. Available from: https://www.pubchem. ncbi.nlm.nih.gov/compound/Vanillic acid.

15. PubChem Myristic acid $\mathrm{C}_{14} \mathrm{H}_{28} \mathrm{O}_{2}$. Available from: https://www. pubchem.ncbi.nlm.nih.gov/compound/Tetradecanoic acid.

16. PubChem Mycol $\mathrm{C}_{20} \mathrm{H}_{40} \mathrm{O}$. Available from: https://www.pubchem.ncbi. nlm.nih.gov/compound/3_7_11_15-tetramethyl-2-hexadecen-1-ol.

17. PubChem Arachidyl Alcohol $\overline{\mathrm{C}}_{20} \mathrm{H}_{42} \mathrm{O}$. Available from: https://www. pubchem.ncbi.nlm.nih.gov/compound/1-eicosanol.

18. PubChem Oleic Acid $\mathrm{C}_{18} \mathrm{H}_{34} \mathrm{O}_{2}$. Available from: https://www.pubchem. ncbi.nlm.nih.gov/compound/oleic acid.

19. PubChem Methyl Linoleate $\mathrm{C}_{19} \overline{\mathrm{H}}_{34} \mathrm{O}_{2}$. Available from: https://www. pubchem.ncbi.nlm.nih.gov/compound/methyl linoleate.

20. PubChem Methyl Stearate $\mathrm{C}_{19} \mathrm{H}_{38} \mathrm{O}_{2}$. Available from: https://www. pubchem.ncbi.nlm.nih.gov/compound/methyl_stearate.

21. PubChem Octadecanal $\mathrm{C}_{18} \mathrm{H}_{36} \mathrm{O}$. Available from: https://www.pubchem. ncbi.nlm.nih.gov/compound/octadecanal.

22. PubChem Octinoxate $\mathrm{C}_{18} \mathrm{H}_{26} \mathrm{O}_{3}$. Available from: https://www.pubchem. ncbi.nlm.nih.gov/compound/Octinoxate.

23. PubChem Hexadecanal $\mathrm{C}_{16} \mathrm{H}_{32} \mathrm{O}$. Available from: https://www. pubchem.ncbi.nlm.nih.gov/compound/hexadecanal.

24. PubChem 9-Octadecenoic Acid $\mathrm{C}_{18} \mathrm{H}_{34} \mathrm{O}_{2}$. Available from: https://www. pubchem.ncbi.nlm.nih.gov/compound/965.

25. PubChem Tetraethylene Glycol Monododecyl Ether $\mathrm{C}_{20} \mathrm{H}_{42} \mathrm{O}_{5}$. Available from: https:/www.pubchem.ncbi.nlm.nih.gov/./Tetraethylene_glycol_ monododecyl_ether.

26. PubChem Ergosterol $\mathrm{C}_{28} \mathrm{H}_{44} \mathrm{O}$. Available from: https://www.pubchem. ncbi.nlm.nih.gov/compound/ergosterol.

27. PubChem Beta-Sitosterol $\mathrm{C}_{29} \mathrm{H}_{50} \mathrm{O}$. Available from: https://www. pubchem.ncbi.nlm.nih.gov/compound/beta-sitosterol.

28. PubChem 16-Hentriacontanone $\mathrm{C}_{31} \mathrm{H}_{62} \mathrm{O}$. Available from: https://www. pubchem.ncbi.nlm.nih.gov/compound/16-Hentriacontanone.

29. Atri NS. Amino acid profile of a basidiomycetous edible mushroomLentinus sajor-caju. Int J Pharm Pharm Sci 2017;9:252-7.

30. Khan F, Chandra R. Effect of physiochemical factors on fruiting body formation in mushroom. Int J Pharm Pharm Sci 2017;9:33-6. 